American Journal of Biochemistry and Biotechnology 5 (4): 226-228, 2009

ISSN 1553-3468

(C) 2009 Science Publications

\title{
Essential Oil of Tanacetum parthenium (L.) from East Part of Kosova
}

\author{
${ }^{1}$ Arben Haziri, ${ }^{1}$ Sevdije Govori-Odai, ${ }^{3}$ Murtezan Ismaili, ${ }^{1}$ Fatmir Faiku and ${ }^{2}$ Imer Haziri \\ ${ }^{1}$ Department of Chemistry, Faculty of Natural Science, University of Pristina, \\ Mother Teresa Street 5, 10000 Prishtine, Republic of Kosova \\ ${ }^{2}$ Department of Veterinary, Faculty of Agricultural, University of Pristina, \\ Mother Teresa Street 5, 10000 Prishtine, Republic of Kosova \\ ${ }^{3}$ Institute for Environment and Health, South East European University Tetovo, \\ Ilindenska bb, 1200, Tetovo, Macedonia
}

\begin{abstract}
Problem statement: We have analyzed the chemical nature of essential oil of Tanacetum parthenium (L.) from East part of Kosova. Approach: The essential oil from aerial part of Tanacetum parthenium (L.), obtained by hidro-distillation was analyzed by GC and GC-MS. Results: Out of 25 peaks, 22 components, which constitute $88 \%$, were identified in oil. The main compounds of Tanacetum parthenium (L.) from east region of Kosova, were camphor (63\%) and camphene (9.6\%). This study demonstrates the occurrence of camphor/camphene chemotype of Tanacetum parthenium (L.) from east part of Kosova. The present study showed the chemical composition of the hydro-distilled oil of Tanacetum parthenium (L.) from East part of Kosova and the results are compared to those reported in the literature. Conclusion: After comparison of our date with those reported in literature we can conclude that genetic and environmental factors play role in determining the composition of essential oil of Tanacetum parthenium (L.).
\end{abstract}

Key words: Tanacetum parthenium (L.), essential oil, east part of Kosova, camphor/camphene chemotype

\section{INTRODUCTION}

Tanacetum parthenium (L.) (known as feverfew) is a medicinal herb which is found in many old gardens $^{[6]}$. It has been used in folk medicine for reducing fever ${ }^{[8]}$.

Essencial oils and extracts of members of genus Tanacetum show antibacterial and antifungal activity ${ }^{[7]}$. The volatile compounds from Tanacetum vulgare have been examined in detail ${ }^{[5]}$. In the case of Tanacetum argyrophyllum, cis-thujone, trans-thujone and 1,8-cineole is reported to predominate in its essential oil ${ }^{[2]}$. Camphor and chrysanthenyl acetate were the main components of the essential oil of Tanacetum parathenium (L.) originated from England and Netherlands ${ }^{[3,4]}$ but in the region of Turkey ${ }^{[1]}$, the main constituents of Tanacetum parathenium (L.) essential oil were camphor, camphene and p-cynene.

The aim of this study was to investigate the chemical nature of essential oil of Tanacetum parathenium (L.) from East part of Kosova and the results are compared to those reported in literature.

\section{MATERIALS AND METHODS}

The aerial part of Tanacetum parthenium (L.) (0.1 g), growing wild in Kamenica (east part of Kosova), was collected in June 2007. Voucher specimens were deposited in the Herbarium of the Department of Veterinary, University of Prishtina (Number AH2). All samples were collected at full flowering stage. The plants were dried at room temperature $\left(22^{\circ} \mathrm{C}\right)$. The essential oil of Tanacetum parathenium (L.) was extracted with steam distillation for $4 \mathrm{~h}$ of $100 \mathrm{~g}$ of air dried plants. The yield was $0.51 \%(\mathrm{v} / \mathrm{w})$.

The analysis of essential oil was carried out by GC and GC-MS. The HP 5890 II chromatograph equipped with an FID detector and capillary column HP-5MS $(30 \times 0.25 \mathrm{~mm})$ was used for quantitative analysis. The GC oven temperature was set at $50^{\circ} \mathrm{C}$ for $3 \mathrm{~min}$, then programmed to $200^{\circ} \mathrm{C}$ at a rate of $3^{\circ} \mathrm{C} \mathrm{min}{ }^{-1}$, then programmed from $200-240^{\circ} \mathrm{C}$ at a rate of $6^{\circ} \mathrm{C} \mathrm{min}^{-1}$. Helium was the carrier gas $\left(1 \mathrm{~mL} \min ^{-1}\right)$. Oil was diluted with acetone (1/100 in acetone, v/v) and $1 \mu \mathrm{L}$ of diluted sample was injected manually. The percentage

Corresponding Author: Arben Haziri, Department of Chemistry, Faculty of Natural Science, University of Pristina, Mother Teresa street 5, 10000 Prishtine, Republic of Kosova 
composition of the essential oil was computed from GC peak areas without correction factors.

Analysis by GC-MS was performed using a chromatograph HP 5890 II GC interfaced to a HP 5972 mass spectrometer (ionization voltage $70 \mathrm{eV}$ ) and equipped with capillary column HP-5MS $(30 \times 0.25$ $\mathrm{mm}$ ). The oven temperature was held at $50^{\circ} \mathrm{C}$ for $2 \mathrm{~min}$, then programmed from $60-200^{\circ} \mathrm{C}$ at a rate of $5^{\circ} \mathrm{C} \mathrm{min}{ }^{-1}$, held for $1 \mathrm{~min}$, then programmed from $200-240^{\circ} \mathrm{C}$ at a rate of $10^{\circ} \mathrm{C} \mathrm{min}^{-1}$, using $\mathrm{He}$ as the carrier gas $(1.0 \mathrm{~mL}$ $\left.\min ^{-1}\right)$. The temperatures of injector and detector were 220 and $290^{\circ} \mathrm{C}$, respectively.

Qualitative analysis was based on a comparison of retention times and indexes on both columns and mass spectra with corresponding data in the literature ${ }^{[1]}$ and computer mass spectra libraries (Wiley and NBS 75K).

\section{RESULTS}

The results obtained by GC and GC-MS analysis of the essential oil of Tanacetum parthenium (L.) are presented in Table 1 . The yield was $0.51 \%$ (v/w). Out of 25 peaks, 22 components which constitute $88 \%$, were identified in oil.

\section{DISCUSSION}

The essential oil from leaves of Tanacetum parthenium (L.), obtained by hidro-distillation was analyzed by GC and GC-MS. 22 components, which constitute $88 \%$, were identified in oil. The main compounds of Tanacetum parthenium (L.) from east region of Kosova, were camphor $(63 \%)$ and camphene $(9.6 \%)$.

Table 1: Chemical composition of Tanacetum parthenium (L.) essential oil (RI: Retention Indices)

\begin{tabular}{llrc}
\hline No. & Components & RI & Percent \\
\hline 1. & tricyclene & 926 & 0.4 \\
2. & $\alpha$-thyjene & 929 & 0.3 \\
3. & $\alpha$-pinene & 939 & 0.5 \\
4. & camphene & 953 & 9.6 \\
5. & $\beta$-pinene & 979 & 0.9 \\
6. & $\alpha$-phellandrene & 1003 & 0.6 \\
7. & $\alpha$-terpinene & 1017 & 0.3 \\
8. & p-cymene & 1026 & 3.3 \\
9. & $\gamma$-terpinene & 1058 & 0.4 \\
10. & chrysanthenone & 1128 & 1.3 \\
11. & camphor & 1146 & 63.0 \\
12. & pinacarvone & 1164 & 0.1 \\
13. & borneol & 1170 & 0.3 \\
14. & terpinen-4-ol & 1177 & 0.9 \\
15. & p-cymen-8-ol & 1183 & 0.8 \\
16. & $\alpha$-terpineol & 1189 & 0.6 \\
17. & myrtenal & 1198 & 0.5 \\
18. & bornyl acetate & 1290 & 3.0 \\
19. & eugenol & 1357 & 0.5 \\
20. & trans-myrtenolacetate & 1387 & 0.3 \\
21. & isobornyl-2-methylbutanoate & 1522 & 0.3 \\
22. & caryophyllene oxide & 1583 & 0.1 \\
\hline
\end{tabular}

Camphor (63\%) in Taracetum parathenium (L.) essential oil from Kosova is in higher quantity than in Tanacetum parathenium (L.) essential oil from Turkey which is $(56.9 \%)$, but quantities of camphen, bornyl acetate and p-cymen are lower than in oil from Turkey $^{[1]}$. Also in Taracetum parthenium (L.) essential oil from Kosova is not present trans-chrysanthenyl acetate which is considered as constituent of Tanacetum parthenium (L.) ${ }^{[4]}$ essential oil. We didn't found carvacrol in Tanacetum parthenium (L.) essential oil from Kosova region, which is present in Tanacetum parthenium (L.) essential oil from Turkey ${ }^{[1]}$ region.

Our data for essential oil of Tanacetum parthenium (L.) differ from those of Tanacetum parthenium (L.) essential oil from Danish origin ${ }^{[3]}$. Danish essential oil characterizes with low amount of camphor (26.7\%) compared with essential oil from Kosova region which contain $63 \%$ of camphor. Also Danish essential oil characterizes with trans-chrysanthenyl acetate $(15.7 \%)$, but in Kosova oil this component is not present as in case of oil of Turkey ${ }^{[1]}$ origin.

The amounts of chemical components in Tanacetum parthenium (L.) essential oil from Kosova region are in agreement with Tanacetum parthenium (L.) essential oil from Turkey ${ }^{[1]}$ region.

\section{CONCLUSION}

The present study presents the chemical composition of the hydro-distilled oil of Tanacetum parthenium (L.). The main compounds of Tanacetum parthenium (L.) from east part of Kosova, were camphor $(63 \%)$ and camphene $(9.6 \%)$. Our results are in agreement with those of Tanacetum parthenium (L.) oil from Turkey ${ }^{[1]}$ origin but differs from those of Tanacetum parthenium (L.) oil from Danish origin ${ }^{[3]}$.

This study demonstrates the occurrence of camphor/camphene chemotype of Tanacetum parthenium (L.) from east part of Kosova. After comparison of our date with those reported in literature we can conclude that genetic and environmental factors play role in determining the composition of essential oil of Tanacetum parthenium (L.).

\section{ACNOWLEDGMENT}

The authors acknowledge the financial support received from the University of Prishtina, Kosova.

\section{REFERENCES}

1. Adams, P.R., 2001. Identification of Essential Oil Components by Gas Chromatography/Quadrupole Mass Spectroscopy. Allured Publishing, Carol Stream, IL., ISBN: 0-931710-85-5. 
2. Akpulat, A.H., B. Tepe, A. Sokmen, D. Daferera and M. Polissiou, 2005. Composition of the essential oils of Tanacetum argyrophyllum (C. Koch) tvzel. Var. argyrophyllum and Tanacetum parthenium (L.) Schultz Bip, (Asteraceae) from Turkey, Biochem. Systemat. Ecol., 33: 511-516. DOI: 10.1016/j.bse.2004.10.006

3. Christensen, L.P., H.B. Jakobsen, E. Paulsen, L. Hodal and K.E. Andersen, 1999. Airborne compositae dermatitis: Monoterpenes and no parthenolide are released from flowering Tanacetum parthenium (feverfew) plants. Arch. Dermatol. $\quad$ Res., 291: 425-431. http://cat.inist.fr/?aModele $=$ afficheN\&cpsidt $=1902$ 769

4. Hendriks, H., R. Bos and J. Woerdenbag, 1996. The essential oil of Tanacetum parthenium (L.) Schultz-Bip. Flav. Frag. J., 11: 367-371. http://cat.inist.fr/?aModele $=$ afficheN\&cpsidt $=2532$ 148
5. Keskitalo, M., E. Pehu and J.E. Simon, 2001. Variation in volatile compounds from tansy (Tanacetum vulgare L.) related to genetic and morphological differences of genotypes. Biochem. Syst. Ecol. 29: 267-285. http://www.ncbi.nlm.nih.gov/pubmed/11152946

6. Mitich, L.W., 1992. Intriguing world of weedsTansy. Weed Technol., 6: 242-244. http://www.jstor.org/stable/3987199

7. Neszmelyi, A., G.W.A. Milne and E. Hethelyi, 1992. Composition of the essential oil of clone 409 of Tanacetum vulgare and 2D NMR investigation of trans-chrysanthenyl acetate. J. Essent. Oil Res., 4: 243-250.

http://www.fao.org/agris/search/display.do?f=./199 2/v1818/US9195054.xml;US9195054

8. Pittler, M.H. and E. Ernst, 2004. Feverfew for preventing migraine. Cochrane Database System. Rev. DOI: 10.1002/14651858.CD002286.pub2 